\title{
The Impact of Greenfield-FDI on Socio-Economic Development of Pakistan
}

\author{
$\operatorname{Raza}$ A. $^{1}$, Azam M. ${ }^{2}$, Tariq M. ${ }^{3}$ \\ ${ }^{1}$ Abdul Wali Khan University Mardan, \\ Khyber Pakhtunkhwa, Pakistan. \\ E-mail: alirazaeco@gmail.com \\ ${ }^{2}$ Abdul Wali Khan University Mardan, \\ Khyber Pakhtunkhwa, Pakistan. \\ E-mail: drazam75@yahoo.com \\ ${ }^{3}$ Abdul Wali Khan University Mardan, \\ Khyber Pakhtunkhwa, Pakistan. \\ E-mail: tariq_noor@awkum.edu.pk
}

A multinational corporation usually invests in foreign countries in two modes of Foreign Direct Investment (FDI) encompasses, Greenfield-FDI (GFDI) and Merger \& Acquisition (M\&A). Mostly Asian countries have experienced improved economic growth from the incoming Greenfield-FDI. The existing studies reveal that GFDI plays undeniably a very important role in the process of economic growth and economic development of a host country's economic performance. Thus, the goal of this study is to know the effect of GFDI inflow on education, health, living standard, and economic development for Pakistan, while using data set from 1990-2018. This study used the Correlation matrix, Augmented Dickey-Fuller (ADF), and Philips Peron (PP) tests for unit root, Auto Distributive Lag model (ARDL), and Error Correction Model (ECM) as estimation techniques. The empirical results indicate that there exists a long-run relationship between GFDI, health, and economic development by Human Development Index (HDI) only. In the long-run GFDI, remittances, and foreign trade have positive, while foreign aid by Official Development Assistance (ODA) and inflation rate negatively affect the life expectancy index, which might mean negative health effects. These findings suggest some important policy measures can be adopted to take more benefits of FDI and stimulate economic growth and socio-economic development.

Ali Raza - PhD Scholar, Department of Economics, Faculty of Business \& Economics, Abdul Wali Khan University Mardan and Lecturer the University of Haripur.

Muhammad Azam - PhD Economics, Faculty of Business \& Economics, Department of Economics.

Muhammad Tariq - PhD Economics, Faculty of Business \& Economics, Department of Economics.

The article was received: $12.06 .2020 /$ The article is accepted for publication: 08.09.2020. 
Key words: greenfield-FDI; Human Development Index; education; health; living standard; Pakistan.

JEL Classification: I15, I25, F24, F35.

DOI: $10.17323 / 1813-8691-2020-24-3-415-433$

For citation: Raza A., Azam M., Tariq M. The Impact of Greenfield-FDI on Socio-Economic Development of Pakistan. HSE Economic Journal. 2020; 24(3): 415-433.

\section{Introduction}

Improvement is always required in the economic and social development of a country. Different alternative measurements are adopted for measuring the welfare of a country, as over decades no consensus was reached on elaborating an informative indicator to accurately measure human development in a country [Qizilbash, 2001]. Accurate measurement of human development in the economy can help policymakers develop more result-oriented policies to expedite improvements of the countries' well-being.

Before the 1970s, the researchers referred to Gross Domestic Product (GDP) based on the national accounting system, as an indicator to measure the economic development in the country, but it is a unidimensional measure of development, which is versatile. However, considering it as a unidimensional measure of welfare, it may be argued that this measure seriously misrepresents the level of welfare [Krugman, 1995]. It was suggested by [Sen, 1998] that the development of a country should be considered in a broader sense, taking into account the availability of good health care facilities, access to modern education, and a decent standard of living. Many researchers contributed to measuring the human development of a country by taking different aspects into account, such as the quality and availability of agriculture products, the level of poverty, crime, environmental pollution, health, housing, nutrition, human capital, education, and life expectancy [Wahedi, 2011; Azam, Gavrila, 2015; Mukherjee, 2017]. Using GDP or GNP per capita as a measurement for human development has a lot of conceptual shortcomings noted by many authors [Kuznets, 1947; Nordhaus, Tobin, 1973; Sen, 2000].

Economics now tend to agree that economic development is the development of people rather than the development of things [Todaro, Smith, 2012]. The HD was introduced by [Haq, 1990], which is a composite measure of education, health, and standard of living and has been adopted by the United Nations as a universal indicator for measuring human development. The value of HDI varies from 0 to 1 , with a higher value indicating a higher level of human development of a country. Countries having an HDI value 0.80 or greater, are on the high end of the human development spectrum, and those who have a value 0.50 remain one the lower end [Sen, 1994].

Firms of developed countries usually invest in developing countries in two modes of FDI, i.e. either GFDI or M\&A. The GFDI is defined as the differences between total FDI inflows and total M\&A sales [Calderon et al., 2004; Wang, Wong, 2009]. Investors choose to invest more in form of GFDI as compared to M\&A. Similarly, GFDI moves from developed countries to developping countries, and as the income gap between poor and rich countries decreases, GFDI decreases as well [Stepanok, 2015]. GFDI contributes to faster growth as a new production capacity. GFDI also adds to a firm's efficiency through employment creation [Meyer, 2003]. 
GFDI is made in different sectors, through which not only firms but governments also get benefits. Some many multinational firms and companies invest in different modes of FDI in foreign countries, but those companies, which invest in GFDI, are the most productive ones [Stepanok, 2015]. Globally, the value of GFDI projects increased from 645 billion US\$ in 2012 to 828 billion US\$ in 2016, with investment in the primary sector GFDI having reached 54 billion US\$, the manufacturing sector 292 billion US\$ and services sector 481 billion US\$ [UNCTAD, 2017]. Globally, GFDI in terms of capital investment decreased by $15.2 \%$ to 662.6 billion US\$ [FDi-Report, 2018]. Some studies found that the impact of GFDI on economic growth is positive [Wang, Wong, 2009; Harms, Meon, 2014; Luu, 2016], while few studies show no relationship between GFDI and economic growth [Calderon et al., 2004; Eren, Zhuang, 2015].

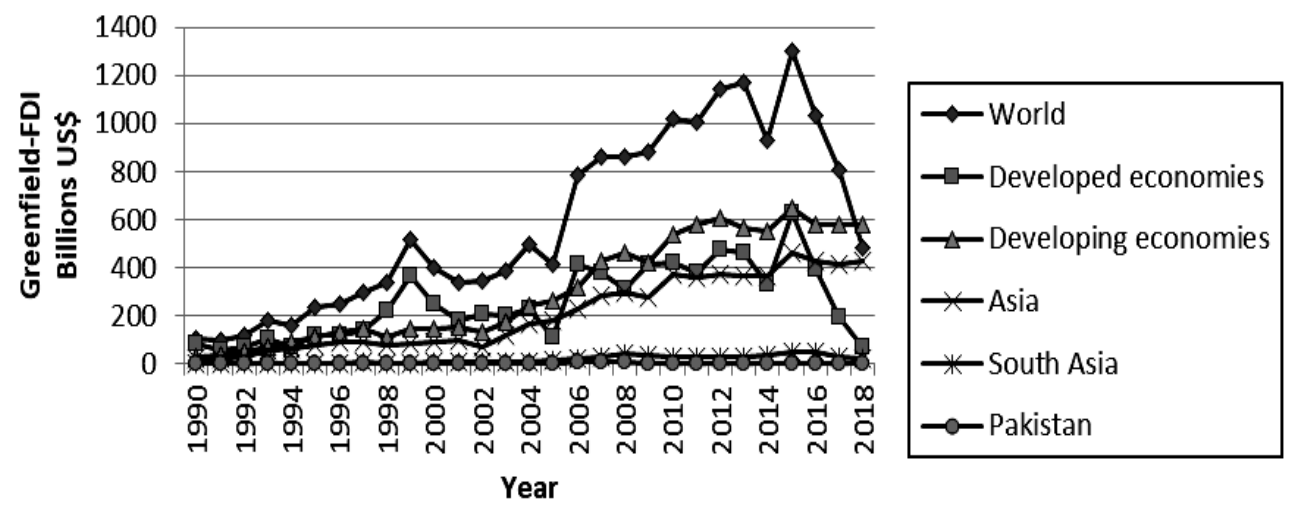

Fig. 1. Flow of Greenfield-FDI to World Economies during 1990-2017, US\$ billions Source: UNDP Statistics, 2019.

Figure 1 shows that in 2007 the world total greenfield investment was about 861 billion US\$, in which developed countries received about 378 billion US\$ and developing countries got around 483 billion US\$. Over the same year, the greenfield investment in Asia was about 229 billion US\$, out of which South Asia received 28.72 billion US\$, while Pakistan attracted about 4.38 billion US\$. The trend in the greenfield investment in the world as a whole grew over time until 2015, and then a downward trend was observed for the years 2017 and 2018.

Pakistan is a developing country and is liberalizing its policies to attract FDI. Pakistan has attracted about 11.9 billion US\$ of FDI from 2013 to 2018, out of which China contributed 4.966 billion US\$, followed by the UK, as the latter allocated 1.6 billion US\$. FDI from the United States totaled 0.813 billion US\$ over the same time frame, the United Arab Emirates contributed 0.425 billion US\$, Japan - 0.281 billion US\$, Hong Kong - 0.858 billion US\$, whereas Switzerland brought 0.600 billion US $\$$. Austria made the investment worth 0.224 billion US $\$$, Netherlands 0.410 billion US $\$$, Italy -0.634 billion US $\$$, Turkey -0.234 billion US $\$$, and others 0.909 billion US\$ [SBP, 2018]. Greenfield investments bring more development to a host country than M\&A, the role of which is dubious [World Investment Report, 1999], and greenfield investment can significantly contribute to the development of a host country [Sniseska, 2008]. According to the UNCTAD (2018) report, the number of greenfield investment start-ups in 2015 was 41, while in 
2016 and 2017 this number fell to 36. Some strong points of Pakistan to attract GFDI are that the country has around 207 million of the population with a declining poverty level, a sizeable middle class, and good demographics. There is abundant and inexpensive labor of workforce and a high GDP growth rate of around 5.2\% seen in recent years. Recently, Pakistan has liberalized its economic policies by launching economic reforms. It has also support from the United States and IMF.

It has been observed that in the past 5 years preceding 2018, the FDI inflows increased, which indicates that policies adopted by the government of Pakistan have been successful. According to the statistics of [UNCTAD, 2018], the FDI inward flow in 2017 alone was 2.746 billion US\$, so that cumulative FDI reached 43.173 billion US\$.

The very first research on this issue has been done by [Afza, Khan, 2009] by taking the greenfield projects done by MNC's to assess the effect of GFDI and economic growth for the economy of Pakistan. Later [Mustafa, Naeem, 2018] discovered the impact of growth drivers on a greenfield investment in Pakistan, but to our knowledge, no comprehensive research is done so far on the relationship of GFDI, health, education, living standards, and economic development. This area of research was ignored by the researchers and was considered unimportant in past.

Pakistan has attracted a lot of GFDI after the financial crisis of 2008 and has also demonstrated improvements in economic growth and development. Therefore, this study was conducted to find out whether GFDI contributed to health, education, income as well. This study has taken the very basic components of economic development like the health index, education index, income index, and HDI, which present a broader picture of the development in the country.

This study attempts:

- $\quad$ to examine the impact of Greenfield-FDI on education in Pakistan;

- to access the impact of Greenfield-FDI on Health in Pakistan;

- to investigate the effect of Greenfield-FDI on living standards in Pakistan;

- to explore the impact of Greenfield-FDI on the economic development of Pakistan.

As these areas were largely ignored by the researchers, there is room to fill this gap, which will enable the practitioners to know more about access to education, health facilities, income conditions, and human development of a society in the future.

The paper is organized in the following way: section 1 discussed objectives, the literature review is presented in section 2, while section 3 broaches data issues and research methodology. Section 4 is about the empirical models of the study. Section 5 clarifies the estimation techniques, applied in the study, and section 6 presents the results, followed by the summary and conclusion (section 7).

\section{Literature Review}

There is very limited literature available on the effect between GFDI and economic growth and vice versa. In the literature, many researchers focused on the FDI-growth nexus and analyzed how FDI inflow contributed to the increase of the economic growth of the host country. Very few scholars have investigated the disaggregated form of FDI and worked on the impact of GFDI, M\&A, and brownfield-FDI. A lot of researchers have discussed the relationship between GFDI and economic growth using panel data, but very few studies were conducted for the time series data. [Afza, Khan, 2009] found some positive results of GFDI related to drivers of FDI in their research. The authors surveyed some 140 multinational corporations in Pakistan and indicated that the 
government should promote its geographical and business advantages to attract GFDI projects. [Zilinali, 2010] argued that GFDI has a greater positive impact on the economic growth and welfare of the host country, while M\&A have negative externalities on the GDP per capita.

[Almsafie et al., 2011] investigated Malaysian data for the period of 1970-2009 using ARDL, Johansen co-integration, and ECM model, and analyzed that GFDI spurred economic growth and also helped to improve the welfare of the Malaysian economy. The study concludes that GFDI and its determinants have a co-integration relationship. Similar results were also mentioned by [Qiu, Wang, 2011] taking the government policies related to attracting GFDI and M\&A while assuming the two-country case. The authors found that both GFDI and M\&A contribute to the welfare of the host country and spur economic growth as well.

[Ara, Das, 2014] suggested that the Indian government should come with some new legislation and improve its existing legislation to attract GFDI in other sectors as well. The authors examined how the performance of the Rourkela steel plant has contributed to the economic growth rate and also had a positive impact on the wellbeing of the local society. The study of [Alam et al., 2016] found the short-run impact of FDI and trade on the life expectancy of Pakistan. The authors researched the data of Pakistan from 1972 to 2013 and suggested that Pakistan should improve its trade, investment, and economic policies that will further have a lasting impact on the health sector.

A positive relationship between GFDI and its growth drivers was found by [Mustafa, Naeem, 2018] while working with the time series data of Pakistan from 2002-2017. The authors concluded that human capital and corporate tax have a positive and significant impact on GFDI, while trade openness, GDP, net foreign assets, market capitalization, and exchange rate are insignificant and negatively related.

The study of [Owen, 2019] found that the announcement of new GFDI projects by a ruling party in Brazil increased the chances for reelection. The author used the data of GFDI projects from 2004-2012 and found that the announcement of GFDI and its reselection by masses have a positive relationship, while GDP and population have an insignificant effect on GFDI.

There is a study conducted by [Hussain et al., 2010] on Pakistani data for the period from 1975 to 2008 using ECM, which found somewhat mixed results. The study revealed that there are no long-run and short-run effects of FDI on HDI. Similarly, GDP has a negative impact on the HDI as the income inequality gap is very high in Pakistan. The study of [Qazi et al., 2017] found the effect of an aggregate FDI on education in Pakistan ignoring the role of GFDI. On the other hand, [Alam et al., 2016] found the effect of total FDI on public health in Pakistan, while ignoring the role of GFDI. Similarly, the study of [Mustafa, Naeem, 2018] found the impact of GDP on GFDI ignoring its effect on living standards. In the past, limited research was done to find out the mutual relationship between GFDI and economic growth in Pakistan, but there exists a gap in the literature studying the effect of GFDI on health, education, living standards, and economic development, as not much attention was paid to these issues in past. So, to fill this gap this study is carried out to explore the impact of GFDI on the education index, life index, GNI index, and HDI.

\section{Data and Methodology}

This research is carried out to find the impact of GFDI on HDI taking into account the respective time series for the years 1990-2018. The data is taken from different sources, such as World Development Indicators [WDI, 2019], United Nations Development Program [UNDP, 2019], 
United Nations Conference on Trade and Development Statistics [UNCTAD, 2019]. The indices on education, health, economic growth, and development were designed by a group of economists under the supervision of Mahbub ul Haq. The group included renowned economists Meghnad Desai, Amartya Sen, Sudhir Anand, Paul Streeten, Frances Stewart, Gustav Ranis, and Keith Griffin [Haq, Ponzio, 2008]. The formulae are given in the Appendix.

[Harrod-Domar, 1946] was the first to introduce capital in the economic growth model under the umbrella of classical theory, to examine its role in the growth of a country. Additionally, this study uses the theory of human capital to describe the role of GFDI in enhancing the education sector of Pakistan. Accordingly, [Kwon, 2009] categorizes education as investments in human capital, which is of similar importance as investments in physical capital. Furthermore, investment in certain welfare projects may lead to increases in life expectancy, which may further spur a country's economic growth [Kwon, 2009]. The overview of the variables used in the study is given as:

Table 1.

\section{List of Variables}

\begin{tabular}{|c|c|c|c|}
\hline Variables & Description & Abbreviations & Data Source \\
\hline Greenfield-FDI & FDI as Greenfield investment in US\$ & GFDI & $\begin{array}{l}\text { UNCTAD } \\
\text { Statistics } 2019\end{array}$ \\
\hline Remittances & $\begin{array}{l}\text { The Migrants transfer payment to his or her } \\
\text { home country. Remittances will be used in US\$ }\end{array}$ & Rem & WDI 2019 \\
\hline Foreign Aid & $\begin{array}{l}\text { Official Development Assistance (concessional } \\
\text { loans and grants) in US\$ }\end{array}$ & ODA & WDI 2019 \\
\hline $\begin{array}{l}\text { Trade } \\
\text { Openness }\end{array}$ & $\begin{array}{l}\text { The addition of exports imports and } \\
\text { then divided by GDP. It is the proxy used } \\
\text { for total trade of a country }\end{array}$ & Trade & WDI 2019 \\
\hline Inflation & $\begin{array}{l}\text { Inflation measured as Consumer Price Index } \\
\text { annual percentage }\end{array}$ & Inf & WDI 2019 \\
\hline Education & $\begin{array}{l}\text { Education index is the geometric mean of } \\
\text { the mean years of schooling and expected years } \\
\text { of schooling }\end{array}$ & Edu Index & $\begin{array}{l}\text { UNDP Statistics } \\
2019\end{array}$ \\
\hline Health & $\begin{array}{l}\text { Life index is measured by the life expectancy } \\
\text { at birth }\end{array}$ & Life Index & $\begin{array}{l}\text { UNDP Statistics } \\
2019\end{array}$ \\
\hline $\begin{array}{l}\text { Standard } \\
\text { of Living }\end{array}$ & $\begin{array}{l}\text { GNI index is measured by gross national inco- } \\
\text { me per capita in purchasing power parity } \\
\text { adjusted as US\$ }\end{array}$ & GNI Index & $\begin{array}{l}\text { UNDP Statistics } \\
2019\end{array}$ \\
\hline $\begin{array}{l}\text { Human } \\
\text { Development } \\
\text { Index }\end{array}$ & $\begin{array}{l}\text { HDI is the measurement of Human Develop- } \\
\text { ment and calculated as geometric mean } \\
\text { of Education index, Life index and GNI index }\end{array}$ & HDI & $\begin{array}{l}\text { UNDP Statistics } \\
2019\end{array}$ \\
\hline
\end{tabular}




\section{Empirical Models}

This study aims to investigate the impact of GFDI on education, health, living standards, and economic development of Pakistan based on the ARDL model is designed by [Pesaran, Pesaran 1997; Pesaran, Shin, 1999; Pesaran et al., 2000, 2001]. This estimation method has advantages over other techniques and can be applied regardless of the variables that are purely integrated of order 0 or 1 . Another advantage of this model is that, if the independent variables are endogenous, even then the outcomes will be efficient [Pesaran et al., 2001].

ARDL Model for Greenfield-FDI and Education. The general form of ARDL model is

$$
Y_{t}=C_{0}+\sum_{i=1}^{p} \alpha_{i} Y_{t-i}+\sum_{i=1}^{q} \beta_{i} X_{t-i}+\varepsilon_{t}
$$

Where $Y_{t}$ is the dependent variable and $X_{t-i}$ are the independent variables, while $p$, $q$ are the optimal lags and $t$ is the time.

This model is developed for the impact of GFDI on education and is used in the study of [Qazi et al., 2017].

$$
\begin{aligned}
& \Delta E d u \text { Index }_{t}=\alpha_{0}+\alpha_{1} \sum_{i=1}^{n 1} \Delta E d u \text { Index }_{t-i}+\alpha_{2} \sum_{i=1}^{n 2} \Delta G F D I_{t-i}+\alpha_{3} \sum_{i=1}^{n 3} \Delta \operatorname{Re} m_{t-i}+ \\
& +\alpha_{4} \sum_{i=1}^{n 4} \Delta O D A_{t-i}+\alpha_{5} \sum_{i=1}^{n 5} \Delta \operatorname{Trade}_{t-i}+\alpha_{6} \sum_{i=1}^{n 6} \Delta \operatorname{Inf} f_{t-i}+\varepsilon_{t} .
\end{aligned}
$$

ARDL Model for Greenfield-FDI and Living Standard. This model is developed to simulate the impact of GFDI on living standards, and this model was used in the studies by [Almsafir et al., 2011; Mustafa, Naeem, 2018].

$$
\begin{aligned}
& \Delta \text { GNIIndex }_{t}=\chi_{0}+\chi_{1} \sum_{i=1}^{n 1} \Delta \text { GNIIndex } x_{t-i}+\chi_{2} \sum_{i=1}^{n 2} \Delta G F D I_{t-i}+\chi_{3} \sum_{i=1}^{n 3} \Delta \operatorname{Re} m_{t-i}+ \\
& +\chi_{4} \sum_{i=1}^{n 4} \Delta O D A_{t-i}+\chi_{5} \sum_{i=1}^{n 5} \Delta \operatorname{Trade}_{t-i}+\chi_{6} \sum_{i=1}^{n 6} \Delta \operatorname{Inf} f_{t-i}+\varepsilon_{t} .
\end{aligned}
$$

ECM Model for Greenfield-FDI and Health. This model is developed to analyze the impact of GFDI on health and was used in the study by [Alam et al., 2016].

$$
\begin{aligned}
& \Delta \text { LifeIndex }_{t}=\beta_{0}+\beta_{1} \text { Life Index }_{t-i}+\beta_{2} \text { GFDI }_{t-i}+\beta_{3} \operatorname{Re}_{t-i}+\beta_{4} O D A_{t-i}+ \\
& +\beta_{5} \text { Trade }_{t-i}+\beta_{6} \operatorname{Inf}_{t-i}+\beta_{7} \sum_{i=1}^{n 1} \Delta \text { Life Index }_{t-i}+\beta_{8} \sum_{i=1}^{n 2} \Delta G F D I_{t-i}+\beta_{9} \sum_{i=1}^{n 3} \Delta \operatorname{Re} m_{t-i}+ \\
& +\beta_{10} \sum_{i=1}^{n 4} \Delta O D A_{t-i}+\beta_{11} \sum_{i=1}^{n 5} \Delta \text { Trade }_{t-i}+\beta_{12} \sum_{i=1}^{n 6} \Delta \operatorname{Inf} f_{t-i}+\varepsilon_{t} .
\end{aligned}
$$


ECM Model for Greenfield-FDI and Socio-Economic Development. This model is developed for to analyze the impact of GFDI on socio-economic development and was used in the study of [Hussain et al., 2010].

$$
\begin{aligned}
& \Delta \text { HDIIndex }_{t}=\gamma_{0}+\gamma_{1} \text { HDIIndex }_{t-i}+\gamma_{2} \text { GFDI }_{t-i}+\gamma_{3} \operatorname{Re} m_{t-i}+\gamma_{4} O D A_{t-i}+ \\
& +\gamma_{5} \text { Trade }_{t-i}+\gamma_{6} \operatorname{Inf}_{t-i}+\gamma_{7} \sum_{i=1}^{n 1} \Delta \text { HDIIndex }_{t-i}+\gamma_{8} \sum_{i=1}^{n 2} \Delta G F D I_{t-i}+\gamma_{9} \sum_{i=1}^{n 3} \Delta \operatorname{Re} m_{t-i}+ \\
& +\gamma_{10} \sum_{i=1}^{n 4} \Delta O D A_{t-i}+\gamma_{11} \sum_{i=1}^{n 5} \Delta \text { Trade }_{t-i}+\gamma_{12} \sum_{i=1}^{n 6} \Delta \operatorname{Inf} f_{t-i}+\varepsilon_{t} .
\end{aligned}
$$

Where $\alpha_{0}, \beta_{0}, \chi_{0}$ and $\gamma_{0}$ is the intercept, $\alpha_{i}, \beta_{i}, \chi_{i}$ and $\gamma_{i}$ are the coefficients of independent variables and $\varepsilon$ is the error term in each model. GFDI is the GFDI of a country, $\operatorname{Re} m$ is the migrant remittances received by the family, Aid is the ODA given by the donor countries, Trade is the trade size, Inf is the inflation and Pop is the total population. The methodology and variables are selected keeping in view their importance on a theoretical and empirical basis. The proxy used in this study for education is Edu Index, for health is Life Index, for living standards is GNI Index, and for economic development is HDI.

After checking the stationarity of each variable, a bound co-integration test is applied, and on the basis of the results then ARDL and ECM model is applied for the analysis. Specifically, for Edu index and GNI index, ARDL model is used and for Life index, while HDI index ECM model is used.

\section{Estimation Techniques}

This study uses Augmented-Dickey Fuller (ADF) and Philips Peron (PP) tests for unit root testing of all variables. The Auto-Regressive Distributive Lag (ARDL) test for the short-run analysis of the variables. The serial correlation LM test is used for an auto-correlation, while for heteroscedasticity this study uses the White test.

\begin{tabular}{|c|c|c|c|c|c|c|c|c|}
\hline \multirow[t]{3}{*}{ Variables } & \multicolumn{4}{|c|}{$\mathrm{ADF}$} & \multicolumn{4}{|c|}{ PP } \\
\hline & \multirow{2}{*}{$\begin{array}{l}\text { Level } \\
\text { Tstat }\end{array}$} & \multirow{2}{*}{$5 \% \mathrm{CV}$} & \multirow{2}{*}{$\frac{1 \text { st Diff }}{\text { Tstat }}$} & \multirow{2}{*}{$5 \% \mathrm{CV}$} & Level & \multirow{2}{*}{$5 \% \mathrm{CV}$} & \multirow{2}{*}{$\begin{array}{l}\text { 1st Diff } \\
\text { Tstat }\end{array}$} & \multirow{2}{*}{$5 \% \mathrm{CV}$} \\
\hline & & & & & Tstat & & & \\
\hline GFDI & -2.424 & -2.997 & -3.023 & -3.00 & -2.011 & -2.994 & -3.943 & -2.997 \\
\hline Rem & 0.158 & -2.997 & -3.107 & -3.00 & 0.461 & -2.994 & -3.666 & -2.997 \\
\hline ODA & -3.461 & -2.997 & - & - & -4.092 & -2.994 & - & - \\
\hline Trade & -1.787 & -2.997 & -4.341 & -3.00 & -1.961 & -2.994 & -5.415 & -2.997 \\
\hline Inf & -1.709 & -2.997 & -3.874 & -3.00 & -2.119 & -2.994 & -6.488 & -2.997 \\
\hline Edu index & 0.032 & -2.997 & -4.422 & -3.00 & -0.032 & -2.994 & -3.422 & -2.997 \\
\hline Life index & -1.388 & -2.997 & -4.141 & -3.00 & -2.477 & -2.994 & -3.521 & -2.997 \\
\hline GNI & 0.533 & -2.997 & -3.134 & -3.00 & 1.178 & -2.994 & -3.081 & -2.997 \\
\hline HDI & -0.859 & -2.997 & -3.125 & -3.00 & -0.853 & -2.994 & -3.415 & -2.997 \\
\hline
\end{tabular}

Table 2.

Unit-Root Testing by ADF and PP Tests 
Table 2, shows the results of ADF and PP tests having the null hypothesis of the unit root of the empirical data. It is observed that all variables i.e. GFDI, Rem, Trade, Inf, Edu Index, Life Index, GNI, and HDI have a unit root at the level greater than the critical value in absolute terms, but at the 1 st difference, these variables become stationary. The ODA is stationary at the level as confirmed by both the ADF and PP tests.

\subsection{Lag Length Selection}

This study used Akaike Information Criterion (AIC) in order to take the appropriate lag length of all variables corresponding to all four models considered in the study.

Table 3.

Lag Length Selection based on AIC

\begin{tabular}{l|c|c|c|c}
\hline \multirow{2}{*}{$\begin{array}{c}\text { Independent } \\
\text { Variables }\end{array}$} & \multicolumn{4}{c}{ Dependent Variables } \\
\cline { 2 - 5 } & Edu Index & Life Index & GNI & HDI \\
\hline \multirow{2}{*}{ GFDI } & 2 & 1 & 2 & 1 \\
Rem & 2 & 1 & 2 & 0 \\
ODA & 1 & 1 & 0 & 1 \\
Trade & 0 & 2 & 1 & 2 \\
Inf & 2 & 1 & 2 & 2 \\
\hline \hline
\end{tabular}

In Table 3, the minimum AIC is found for each model with the maximum lag length to carry out further analysis. Each model with the appropriate lag length is shown with its minimum AIC.

\subsection{Short-run and Long-run Analysis}

This section examines the short and long-run model estimates based on results from the bound co-integration test to explain the overall results of the study. In the bound test if the calculated test-statistic value lies outside the upper critical value, then it indicates that a long-run relationship exists among variables, while if the calculated value is below the lower critical value, then a vice versa situation occurs. However, if the calculated value falls in between lower and upper critical value, then an inconclusive result creates doubts if a long-run relationship holds or not.

It can be seen from Table 4 that the calculated value of the F-test statistic value of the Edu index and GNI does not lie in between the critical values, so there is no co-integration between the Edu index and GFDI, and that of GNI and GFDI as well. It is also observed that cointegration between Life Index and GFDI exists, and it also exists between HDI and GFDI in the presence of all other controlled variables. However, results also indicate that GFDI with help of controlled variables is unable to have a long-run relationship against Edu Index and GNI. 
Results of Bound Co-integration Test

\begin{tabular}{l|c|c|cc}
\hline Models & $\begin{array}{c}\text { F-test statistic } \\
\text { (calculated value) }\end{array}$ & $\begin{array}{c}5 \% \text { lower critical } \\
\text { value I(0) }\end{array}$ & $\begin{array}{c}5 \% \text { upper critical } \\
\text { value I(1) }\end{array}$ & Decision \\
\hline Edu Index & 1.320 & 2.62 & 3.79 & $\begin{array}{l}\text { Co-integration } \\
\text { doesn't exist }\end{array}$ \\
Life Index & 11.110 & 2.62 & 3.79 & Co-integration exist \\
GNI & 2.495 & 2.62 & 3.79 & $\begin{array}{l}\text { Co-integration } \\
\text { doesn't exist }\end{array}$ \\
HDI & 11.796 & 2.62 & 3.79 & Co-integration exist \\
\hline \hline
\end{tabular}

Model Estimation of Education Index Using ARDL Model

Table 5.

\begin{tabular}{lrcccc}
\hline \multicolumn{1}{c|}{ Variables } & \multicolumn{1}{c}{ Coef. } & Std. Err & t-statistic & Prob. \\
\hline Constant & 0.3719356 & 0.0939972 & 3.96 & 0.002 \\
D1_Edu & 4.236023 & 1.183839 & 3.58 & 0.004 \\
D2_Edu & -2.313911 & 0.8505684 & -2.72 & 0.019 \\
GFDI & 0.0007878 & 0.0001376 & 5.73 & 0.000 \\
D1_GFDI & -0.0005866 & 0.0002376 & -2.47 & 0.031 \\
Rem & 0.0170578 & 0.0027032 & 6.31 & 0.000 \\
D1_Rem & -0.0031103 & 0.0069522 & -0.45 & 0.663 \\
ODA & -0.0152735 & 0.0118109 & -1.29 & 0.22 \\
Trade & -0.6019592 & 0.3482448 & -1.73 & 0.11 \\
D1_Trade & 0.5447249 & 0.4019278 & 1.36 & 0.201 \\
D2_Trade & -0.1889469 & 0.2093274 & -0.9 & 0.384 \\
Inf & 0.0024256 & 0.0021868 & 1.11 & 0.289 \\
D1_Inf & -0.0056299 & 0.0023402 & -2.41 & 0.033 \\
D2_Inf & 0.0029525 & 0.0013204 & 2.24 & 0.045 \\
\hline \hline
\end{tabular}

Table 5 shows estimates of models having Edu Index as a dependent variable as no cointegration exists between Edu index and GFDI. So, the estimation is done by the ARDL model by using the lag length of all variables mentioned in Table 3 . The findings also confirmed that GFDI and remittances have a statistically significant and positive effect on the education of Pakistan. These results are also confirmed by the study of [Qazi et al., 2017]. On the other side, 
ODA and trade have a negative but insignificant effect, and the results are consistent with the study of [Kemal, Jilani, 2016]. The authors confirmed that ODA is insignificantly related to the primary, secondary, and higher education sector of Pakistan.

Model Estimation of GNI Using ARDL Model

Table 6.

\begin{tabular}{lr|c|c|c}
\hline \multicolumn{1}{c}{ Variable } & \multicolumn{1}{c|}{ Coef. } & Std. Err & t-statistic & Prob. \\
\hline Constant & 0.5593837 & 0.0284743 & 19.65 & 0.000 \\
D1_GNI & 1.25645 & 0.6125582 & 2.05 & 0.065 \\
D2_GNI & -0.8382082 & 0.4757179 & -1.76 & 0.106 \\
GFDI & 0.0002746 & 0.0000439 & 6.26 & 0.000 \\
D1_GFDI & -0.0001275 & 0.0000875 & -1.46 & 0.173 \\
D2_GFDI & 0.0000745 & 0.0000605 & 1.23 & 0.244 \\
Rem & 0.0064754 & 0.0009474 & 6.84 & 0.000 \\
ODA & -0.0013933 & 0.0054584 & -0.26 & 0.803 \\
D1_ODA & -0.0031886 & 0.0032159 & -0.99 & 0.343 \\
Trade & -0.1340987 & 0.1083074 & -1.24 & 0.241 \\
D1_Trade & 0.0642792 & 0.1125494 & 0.57 & 0.579 \\
D2_Trade & 0.0134223 & 0.0538941 & 0.25 & 0.808 \\
Inf & 0.0002304 & 0.0007649 & 0.3 & 0.769 \\
D1_Inf & -0.0003353 & 0.0008413 & -0.4 & 0.698 \\
D2_Inf & -0.0001335 & 0.0005035 & -0.27 & 0.796 \\
\hline \hline
\end{tabular}

Table 6, shows that GNI as a dependent variable can be obtained based on maximum lags, identified in Table 4 . The findings confirm that there is a statistically significant and positive effect of GFDI and remittances on life standard, and these results were confirmed by [Afza, Khan, 2009]. ODA and trade have an insignificant and negative relationship with GNI, and these results correspond to the study of [Adedokun, 2017], the author revealed that aid is harmful to the developing economies. It is observed that the majority of the lagged variables have either a positive impact or negative impact, but this impact is not significant.

Table 7, shows the results of the Error Correction Model (ECM), in which the magnitude and sign of the coefficient of Error Correction Term (ECT) show a short-term adjustment process. This term suggests that $0.01 \%$ correction is made in a year to converge to the equilibrium path. A long-run positive relationship exists between GFDI and health, while between remittances and health there is a significant and positive relationship. The findings of this study are also supported by the study of [Alam et al., 2016]. On the other hand, a negative and insignificant relationship exists among ODA, trade, and health, whereas inflation has a positive but statistically insignificant effect on health. The findings of this study are also consistent with the study of [Williamson, 2008], who pointed out that in developing countries aid has no relationship with the health. 
Table 7.

Error Correction Model (ECM) Estimation of Life Index

\begin{tabular}{lccccc}
\hline \multicolumn{1}{c}{ Variable } & Coef. & Std. Err. & t-statistic & Prob. \\
\hline ECT & -0.0136 & 0.01354 & -1 & 0.336 \\
\hline GFDI & \multicolumn{5}{c}{ LR } \\
Rem & 0.00093 & 0.00038 & 2.45 & 0.044 \\
ODA & 0.0092 & 0.00412 & 2.23 & 0.043 \\
Trade & -0.0256 & 0.05222 & -0.49 & 0.632 \\
Inf & -0.8233 & 0.72233 & -1.14 & 0.277 \\
\hline & 0.01458 & 0.01437 & 1.01 & 0.33 \\
\hline D1_GFDI & $1.5 \mathrm{E}-05$ & SR & & 0.041 \\
D1_Rem & 0.00086 & $7.51 \mathrm{E}-06$ & 1.93 & 0.003 \\
D1_ODA & -0.0003 & 0.00023 & 3.75 & 0.629 \\
D2_ODA & 0.00079 & 0.00056 & -0.5 & 0.043 \\
D1_Trade & 0.00632 & 0.00035 & 2.26 & 0.22 \\
D1_Inf & -0.0002 & 0.00488 & 1.29 & 0.002 \\
D2_Inf & $-3 \mathrm{E}-05$ & $3.9 \mathrm{E}-05$ & -4 & 0.342 \\
Constant & 0.0151 & $3.3 \mathrm{E}-05$ & -0.99 & 1.48 \\
\hline \hline
\end{tabular}

Error Correction Model (ECM) Estimation of HDI Index

\begin{tabular}{lccccc}
\hline \multicolumn{1}{c}{ Variable } & Coef. & Std. Err. & t-statistic & Prob. \\
\hline ECT & -0.0262 & 0.0439 & 1.43 & 0.15 \\
\hline \multicolumn{5}{c}{ LR } \\
GFD & 0.00045 & $8.7 \mathrm{E}-05$ & 5.24 & 0.000 \\
Rem & 0.01672 & 0.0018 & 9.28 & 0.000 \\
ODA & -0.0615 & 0.01408 & -4.36 & 0.001 \\
Trade & -0.6033 & 0.17411 & -3.46 & 0.005 \\
Inf & 0.00495 & 0.0012 & 4.14 & 0.001
\end{tabular}




\begin{tabular}{l|c|c|c|c}
\multicolumn{1}{c}{ Variable } & Coef. & Std. Err. & t-statistic & Prob. \\
\hline \multicolumn{7}{c}{ SR } \\
\hline D1_Rem & 0.00311 & 0.00129 & 2.41 & 0.033 \\
D1_ODA & -0.0104 & 0.0027 & -3.85 & 0.002 \\
D2_ODA & -0.0095 & 0.00146 & -6.51 & 0.000 \\
D1_Trade & -0.1059 & 0.03005 & -3.53 & 0.004 \\
D2_Trade & -0.0519 & 0.02801 & -1.85 & 0.089 \\
D1_Inf & 0.00058 & 0.00019 & 3 & 0.011 \\
D2_Inf & 0.00052 & 0.00013 & 4.05 & 0.002 \\
Constant & -0.1584 & 0.02597 & -6.1 & 0.000 \\
\hline \hline
\end{tabular}

Table 8, shows the results of the Error Correction Model (ECM), in which the magnitude and sign of the coefficient of ECT suggest that $0.02 \%$ correction is made in a year to converge to the equilibrium path. GFDI and remittances have a significant and positive effect on the economic development of Pakistan; these results are also confirmed by the study of [Hussain et al., 2010]. ODA and trade have a negative sign, but significantly related to the HDI, and the results are consistent with the study of [Kumler, 2007], whereas inflation is significantly positively related to HDI. The author noted that aid is not beneficial for the economic development of a developing country.

\subsection{Diagnostic Test}

Most of the time series have the problem of serial correlation. To check the serial correlation in the data, this study applied the Breusch-Godfrey Serial Correlation LM test, while for checking the heteroscedasticity in the model, the White test was used and has found the following results.

Table 9.

Diagnostic Tests for Hetroskedasticity and Autocorrelation

\begin{tabular}{|c|c|c|c|c|}
\hline & Edu Index & Life Index & GNI & HDI \\
\hline Hetroskedasticity & $\begin{array}{l}\text { F-Stat }=1.695230 \\
\text { Prob. } F(13,11)= \\
0.1936\end{array}$ & $\begin{array}{l}\text { F-Stat }=1.176316 \\
\text { Prob. } F(14,10)= \\
0.4791\end{array}$ & $\begin{array}{l}\text { F-Stat }=0.136180 \\
\text { Prob. } F(11,13)= \\
0.8690\end{array}$ & $\begin{array}{l}\text { F-Stat }=0.136180 \\
\text { Prob. } F(14,10)= \\
0.9995\end{array}$ \\
\hline Autocorrelation & $\begin{array}{l}\text { F-Stat }=1.219065 \\
\text { Prob. } F(4,7)= \\
0.3831\end{array}$ & $\begin{array}{l}\text { F-Stat }=0.2772 \\
\text { Prob. } F(4,8)= \\
0.8847\end{array}$ & $\begin{array}{l}\text { F-Stat }=1.888876 \\
\text { Prob. } F(4,9)= \\
0.1966\end{array}$ & $\begin{array}{l}\text { F-Stat }=0.992715 \\
\text { Prob. } F(4,6)= \\
0.4782\end{array}$ \\
\hline Decision & $\begin{array}{l}\text { No hetroskedasti- } \\
\text { city and autocor- } \\
\text { relation }\end{array}$ & $\begin{array}{l}\text { No hetroskedasti- } \\
\text { city and autocor- } \\
\text { relation }\end{array}$ & $\begin{array}{l}\text { No hetroskedasti- } \\
\text { city and autocor- } \\
\text { relation }\end{array}$ & $\begin{array}{l}\text { No hetroskedasti- } \\
\text { city and autocor- } \\
\text { relation }\end{array}$ \\
\hline
\end{tabular}


Table 9, shows that there is no heteroscedasticity and autocorrelation in all four models constructed for the estimations of coefficients of targeted variable and controlled variables.

\section{Discussion on Results}

As the research results demonstrate, the GFDI has a positive effect on education, health, living standards, and economic development of Pakistan. The same results were found in the study of [Qazi et al., 2017]. The authors conduct a study on the data of Pakistan from 1972 to 2013 using the ARDL model and explored that FDI has a positive effect on the higher education of Pakistan. This study finds that there is a long-run effect of GFDI on education and the same results were found by [Qazi et al., 2017], where FDI and higher education have a long-run unidirectional positive impact. In this study, GFDI has a positive relationship with the economic growth of Pakistan and the same results were found in the study of [Afza, Khan, 2009]. The authors researched Pakistani data and concluded that GFDI is beneficial for the economy.

In this present study remittance and trade has a positive and significant impact on HDI but trade is negatively related to health. Whereas ODA and inflation have a negative impact on education, health, living standard, and economic development of Pakistan.

The present study finds both long and short-run significantly positive impacts of GFDI on health and the same results were found in the study of [Alam et al., 2016]. In the case of HDI, as this index is composed of education, health, and living standard but as health and economic growth long-run relation with GFDI, so HDI has also a long-run relationship with GFDI. But some mix and different results were found by [Hussain et al., 2010] and concluded that there is no clear relationship between FDI, economic growth, and HDI.

This study has taken the basic components of the welfare of a society that express the basic needs like health, education, and income. HDI is considered as the most appropriate measurement of economic development of human capital which focuses on the quantitative as well as qualitative progress. So this paper has tried to measure the human capital as precisely as it can be and HDI focuses on the life quality and economic situation of all individuals.

\section{Summary and Conclusion}

This study aims to analyze the impact of GFDI on health, education, living standards, and economic development of Pakistan by analyzing the time series from 1990 to 2018. The study used a correlation matrix for the identification of strength and direction of correlation, ADF, and PP tests were used for unit root testing and the bound co-integration test for the existence of co-integration. ARDL model was used for the long-run analysis, while the error correction model was used for the short-run analysis. In the end, some diagnostic tests were performed to find the serial correlation and heteroscedasticity. The results revealed that GFDI has a positive impact on education, health, living standards, and economic development. In the case of Pakistan, there is a minimum number of investments made by multinational companies in the education sector, which gives no long-run relationship between education and GFDI, while in the case of health some good MNCs are working in Pakistan, having invested multi-billion dollars in the health sector. So, the results confirmed that this relationship holds, and a long-run influence of GFDI on health exists. The multi-billion-dollar investments were made in the health sector, and 
many people benefitted from it having been employed by this sector. With this attraction, people could earn a good level of income but still, this investment, i.e. GFDI, has not increased significantly the income level in the country as a whole. Thus, no long-run relationship holds. At the same time, GFDI has a positive effect on the overall welfare, i.e. HDI of a country.

The study suggests that the government should improve its business policies to attract more and more GFDI in education, health, and economic sector, so that it may have a more fruitful effect on health and living standards, especially on the overall quality of education of Pakistan.

\section{Appendix.}

Table A.

Descriptive Statistics Table

\begin{tabular}{l|c|c|c|c|c}
\hline \multicolumn{1}{c}{ Variable } & Obs & Mean & Std. Dev. & Min & Max \\
\hline GFDI & 28 & 37.8999 & 33.4134 & 11.2774 & 136.007 \\
Rem & 28 & 3.81825 & 2.71062 & 0.88336 & 8.94074 \\
ODA & 28 & 1.22955 & 0.37202 & 0.58937 & 1.854 \\
Trade & 28 & 0.3196 & 0.0358 & 0.25582 & 0.39187 \\
Inf & 28 & 8.49963 & 4.17472 & 2.53952 & 20.2861 \\
Life index & 28 & 0.66936 & 0.03117 & 0.616 & 0.717 \\
Edu index & 28 & 0.30454 & 0.06943 & 0.205 & 0.411 \\
GNI & 28 & 0.55429 & 0.02482 & 0.523 & 0.601 \\
HDI & 28 & 0.48096 & 0.05033 & 0.404 & 0.55 \\
\hline \hline
\end{tabular}

Formulae:

$$
\begin{aligned}
& \text { Index }_{\text {it }}=\frac{\text { Actual } \text { value of Indicator }_{i t}-\text { Minimum value }}{\text { Maximum value }- \text { Minimum value }} ;
\end{aligned}
$$

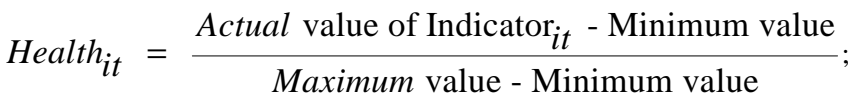

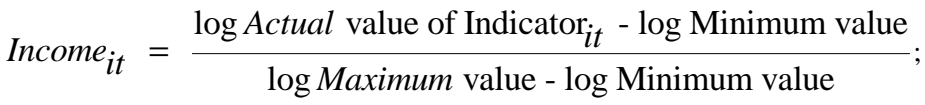

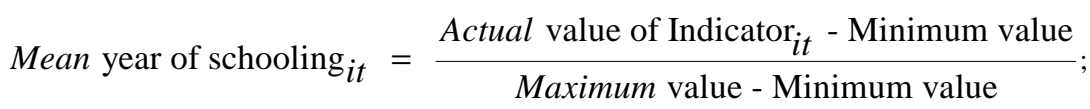


Expected Year of Schooling ${ }_{i t}=\frac{\text { Actual } \text { value of } \text { Indicator }_{i t}-\text { Minimum value }}{\text { Maximum value }- \text { Minimum value }}$;

$E d u_{i t}$ index $=\frac{\sqrt{\mathrm{MYS}_{i t} \cdot \mathrm{EYS}_{i t}}}{\text { combined education index }}$ it

$H D I=\sqrt[3]{\text { Income index } \cdot \text { Health index } \cdot \text { Edu index }}$.
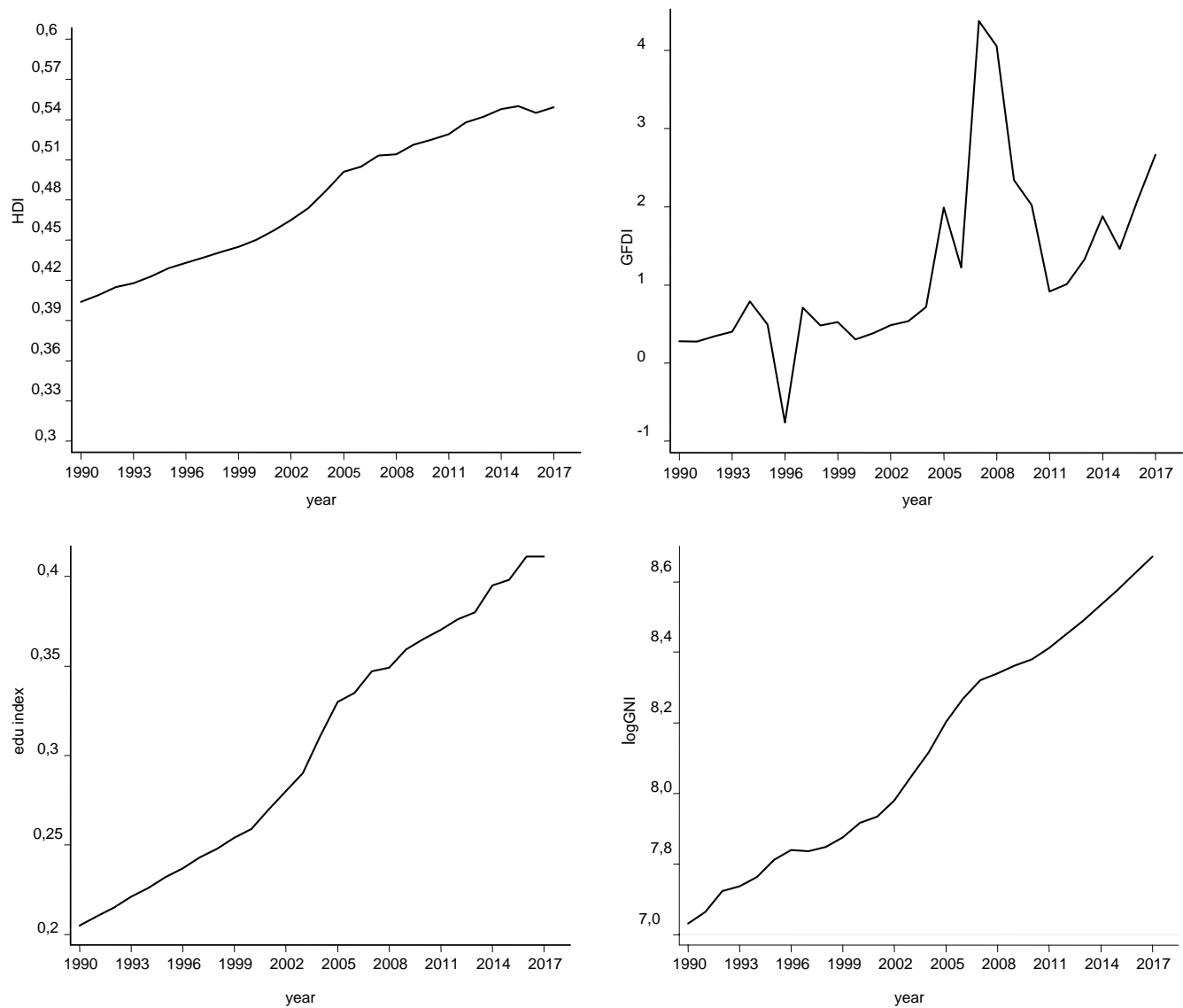

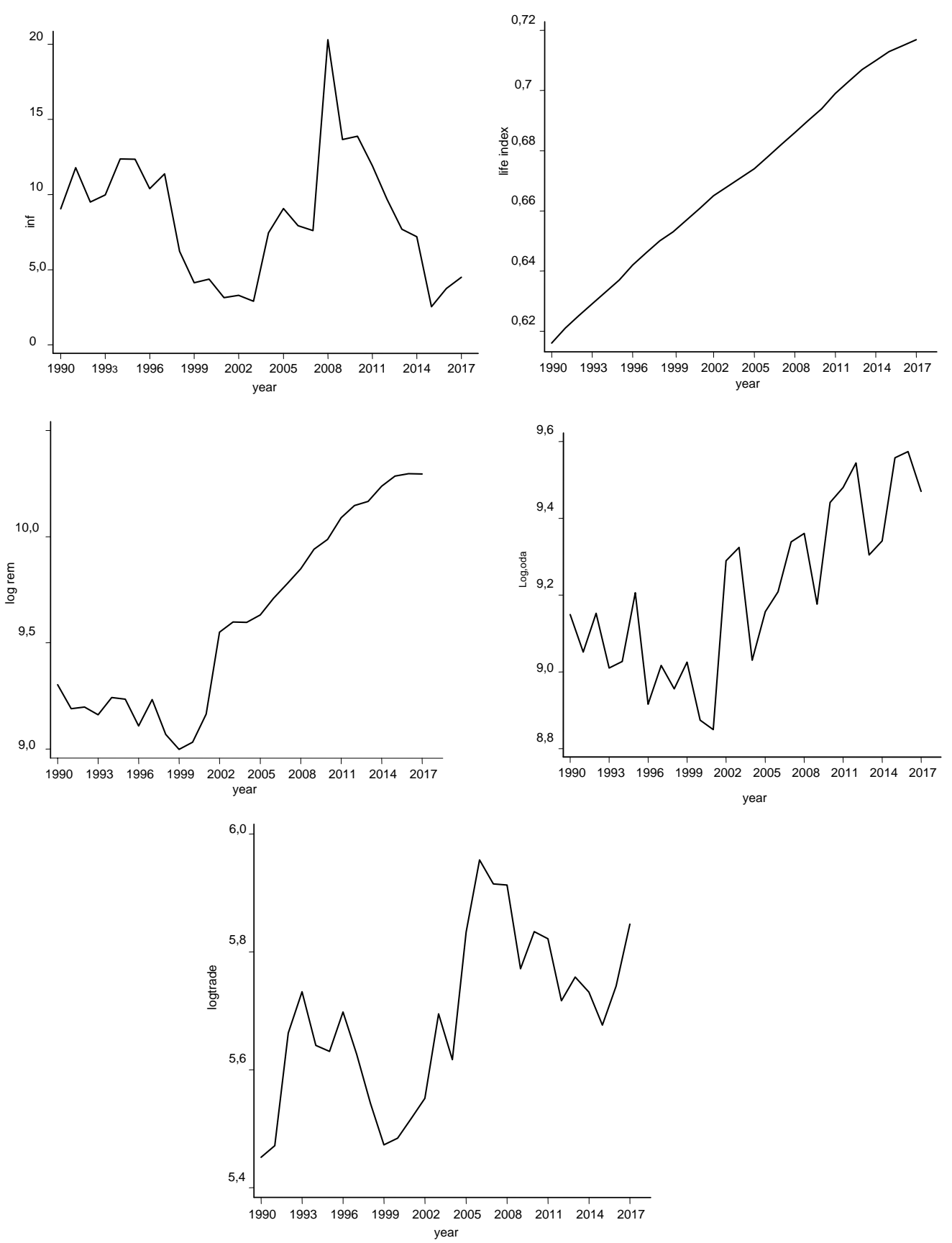

Fig. 2. Graphical moments of all variables over time from 1990-2018 


\section{References}

Adedokum A.J. (2017) Foreign Aid, Governance and Economic Growth in Sub-Saharan Africa: Does One Cap Fit All? African Development Review, 29, 2, pp. 184-196.

Afza T., Khan M.M.S. (2009) Greenfield in Pakistan: Is it Really Green? An Empirical Investigation. American Journal of Scientific Research, 4, 1, pp. 59-71.

Akinkugbe 0., Yinusa 0. (2009) ODA and Human Development in Sub-Saharan Africa: Evidence from Panel Data. Presentation at the $14^{\text {th }}$ Annual Conference On Econometric Modelling For Africa, Abuja, Nigeria, pp. 8-10.

Alam M.S., Raza S.A., Shahbaz M., Abbas Q. (2016) Accounting for Contribution of Trade Openness and Foreign Direct Investment in Life Expectancy: The Long-Run and Short-Run Analysis in Pakistan. Social Indicators Research, 129, 3, pp. 1155-1170.

Almsafir M.K., Latif N.W.A., Bekhet H.A. (2011) Analyzing the Green Field Investment in Malaysia from 1970 to 2009: A Bound Testing Approach. Australian Journal of Basic and Applied Sciences, 5, 3, pp. 561570.

Arisman A. (2018) Determinant of Human Development Index in ASEAN Countries. Signifikan: Jurnal Ilmu Ekonomi, 7, 1, pp. 113-122.

Azam M., Gavrila L. (2015) Inward Foreign Capital Flows and Economic Growth in African Countries. Journal of Applied Economic Sciences, 10, 33, pp. 362-371.

Calderón C., Loayza N., Servén L. (2004) Greenfield Foreign Direct Investment and Mergers and Acquisitions: Feedback and Macroeconomic Effects. Policy Research Working Paper; no 3192. World Bank, Washington, DC.

Das K.K., Ara A. (2014) Role of Greenfield Project on Growth and Prosperity: Case Study of Rourkela Steel Plant. British Journal f Research, 1, 1, pp. 16-25.

Economic Survey of Pakistan, 2018.

Eren M., Zhuang H. (2015) Mergers and Acquisitions Versus Greenfield Investment, Absorptive Capacity and Economic Growth: Evidence from 12 New Member States of The European Union. Eastern European Economics, 53, 2, pp. 99-123.

Fdi-Report, 2018.

Haq K., Ponzio R. (2008) Pioneering the Human Development Revolution: An Intellectual Biography of Mahbub ul Haq. Oxford University Press.

Haq M. ul. (1999) Reflections on Human Development. Oxford University Press.

Harms P., Méon P.G. (2011) An FDI Is An FDI Is An FDI. The Growth Effects of Greenfield Investment and Mergers and Acquisitions in Developing Countries. Working Paper 11.10, Study Center Gerzensee, Schweizerische Nationalbank.

Hicks N., Streeten P. (1979) Indicators of Development: The Search for a Basic Needs Yardstick. World Development, 7, 6, pp. 567-580.

Hussain A., Majeed S., Muhammad S.D., Lal I. (2010) Impact of Globalization on HDI (Human Development Index): Case Study of Pakistan. European Journal of Social Sciences, 13, 1, pp. 46-57.

Kemal M.A., Jilani A. (2016) 9 Impact of Foreign Aid in Education on Educational Outcomes. Pakistan Institute of Development Economics, 139, pp. 1-9.

Krugman P.R. (1995) Peddling Prosperity: Economic Sense and Nonsense in the Age of Diminished Expectations. WW Norton \& Company.

Kumler T.J. (2007) The Impact of Foreign Aid on Development and Aggregate Welfare in Developing Countries, Honors Project, 19.

Kuznets S. (1947) Measurement of Economic Growth. The Journal of Economic History, 7, 1, pp. 10-34. 
Kwon D.B. (2009) Human Capital and its Measurement. The 3rd OECD World Forum on "Statistics, Knowledge and Policy" Charting Progress, Building Visions, Improving Life, Busan, Korea 27-30 October 2009. Luu H. (2016) Greenfield Investments, Cross-Border M\&A and Economic Growth in Emerging Countries. Economic and Business Letter, 5, 3, pp. 87-94.

Marinescu N. (2016) Greenfields and Acquisitions: A Comparative Analysis. Bulletin of the Transilvania University of Brasov. Economic Sciences, Series V, 9, 1, pp. 295-300.

Mukherjee R. (2017) Foreign Capital Inflow and its Welfare Implications in a Developing Country Context. Economics: The Open-Access, Open-Assessment E-Journal, 11, 1, pp. 1-16.

Mustafa S., Naeem M. (2018) Growth Drivers of Greenfield Investment in Pakistan: Time Period of 2002-2017. Research Journal of Finance and Accounting, 9, 19, pp. 87-95.

Nordhaus W.D., Tobin J., Moss M. (1973) The Measurement of Economic and Social Performance. Studies in Income and Wealth, 38, 3, pp. 509-564.

Owen E. (2019) Foreign Direct Investment and Elections: The Impact of Greenfield FDI on Incumbent Party Reelection in Brazil. Comparative Political Studies, 52, 4, pp. 613-645.

Park C.Y., Byun H.S., Lee H.H. (2012) Assessing Factors Affecting M\&As Versus Greenfield FDI in Emerging Countries. Papers and Briefs. Economics Working Papers, 293.

Qazi W., Sharif A., Raza S.A. (2017) Foreign Direct Investment and Higher Education Development in Pakistan: Evidence from Structural Break Testing. International Journal of Education Economics and Development, 8, 1, pp. 1-21. Qizilbash M. (2001) Sustainable Development: Concepts and Rankings. Journal of Development Studies, 37,3 , pp. $134-161$.

Sanchez-Loor D.A., Zambrano-Monserrate M.A. (2015) Causality Analysis between Electricity Consumption, Real GDP, Foreign Direct Investment, Human Development and Remittances in Colombia, Ecuador and Mexico. International Journal of Energy Economics and Policy, 5, 3, pp. 746-753. Sen A. (1994) Human Development Index: Methodology and Measurement. Sen A. (1998) Mortality as an Indicator of Economic Success and Failure. The Economic Journal, 108,1 , pp. $1-25$.

Sen A. (2000) A Decade of Human Development. Journal of Human Development, 1, 1, pp. 17-23.

Slottje D.J. (1991) Measuring the Quality of Life across Countries. The Review of Economics and Statistics, 73, 4, pp. 684-693.

Snieska V. (2008) A New Textbook on International Trade. Inzinerine Ekonomika-Engineering Economics, 1, pp. 120-121.

Stepanok I. (2015) Cross-Border Mergers and Greenfield Foreign Direct Investment. Review of International Economics, 23, 1, pp. 111-136.

UNCTAD (2016) Data Center. Unctadstat. Unctad. Org. Available at: http://unctadstat.unctad.org/ wds/TableViewer/tableView.aspx?

UN (2017) World Investment Report 2017: Investment and The Digital Economy. United Nations Conference on Trade and Development. Wahedi A.U. (2011) Capital Flows, Political Performance and Development. Ph.D Thesis, Portland State University. Wang M., Sunny Wong M.C. (2009) What Drives Economic Growth. The Case of Cross-Border M\&A and Greenfield FDI Activities. Kyklos, 62, 2, pp. 316-330. Williamson C.R. (2008) Foreign Aid and Human Development: The Impact of Foreign Aid to the

Health Sector. Southern Economic Journal, 75, 1, pp. 188-207. The World Bank (2019) World Development Indicators.

World Investment Report (1999). Available at: www.Unctad.org/En/Docs/Wir1999_En.Pdf.

Zhuang H. (2017) The Effect of Foreign Direct Investment on Human Capital Development in East Asia. Journal of the Asia Pacific Economy, 22, 2, pp. 195-211.

Zhuang H., Griffith D. (2013) The Effect of Mergers \& Acquisitions and Greenfield FDI on Income Inequality. International Journal of Applied Economics, 10, 1, pp. 29-38.

Žilinskè A. (2010) Negative and Positive Effects of Foreign Direct Investment. Economics and Management, 15, pp. 332-336. 